\title{
The 372 T/C genetic polymorphism of TIMP-1 is associated with serum levels of TIMP-1 and survival in patients with severe sepsis
}

Leonardo Lorente ${ }^{1 *}$, Mar Martín², Fátima Plasencia ${ }^{3}$, Jordi Solé-Violán ${ }^{4}$, José Blanquer$^{5}$, Lorenzo Labarta ${ }^{6}$, César Díaz ${ }^{7}$ Juan María Borreguero-León ${ }^{8}$, Alejandro Jiménez ${ }^{3}$, José Antonio Páramo ${ }^{9}$, Josune Orbe ${ }^{9}$, José A Rodríguez ${ }^{9}$ and Eduardo Salido ${ }^{3}$

\begin{abstract}
Introduction: Previous studies have found higher circulating levels of tissue inhibitor of matrix metalloproteinase (TIMP)-1 in nonsurviving septic patients than in surviving septic patients, and an association between the $372 \mathrm{~T} / \mathrm{C}$ genetic polymorphism of TIMP-1 and the risk of developing certain diseases. However, the relationship between genetic polymorphisms of TIMP-1, circulating TIMP-1 levels and survival in patients with severe sepsis has not been examined, and this was the objective of the study.

Methods: This multicentre, prospective, observational study was carried out in six Spanish ICUs. We determined the 372 T/C genetic polymorphism of TIMP-1 (rs4898), serum levels of TIMP-1, matrix metalloproteinase (MMP)-9, MMP-10, TNF $\alpha$, IL-10 and plasma plasminogen activator inhibitor-1 (PAI-1). Survival at 30 days from ICU admission was the endpoint assessed. The association between continuous variables was carried out using Spearman's rank correlation coefficient or Spearman's rho coefficient. Multivariate logistic regression analysis was applied to determine the association between the $372 \mathrm{~T} / \mathrm{C}$ genetic polymorphism and survival 30 days from ICU admission.

Results: Of 275 patients with severe sepsis, 80 had genotype CC, 55 had genotype CT and 140 had genotype $T$ of the 372 T/C genetic polymorphism of TIMP-1. Patients with the T allele showed higher serum levels of TIMP-1 than patients without the $T$ allele $(P=0.004)$. Multiple logistic regression analysis showed that the $T$ allele was associated with higher mortality at 30 days (odds ratio $=2.08 ; 95 \%$ confidence interval $=1.06$ to $4.09 ; P=0.03$ ). Survival analysis showed that patients with the T allele presented lower 30-day survival than patients without the T allele $\left(\chi^{2}=5.77 ; P=0.016\right)$. We found an association between TIMP-1 levels and levels of MMP-9 $(\rho=-0.19 ; P=0.002)$, MMP-10 $(\rho=0.55 ; P<0.001)$, TNFa $(\rho=0.56 ; P<0.001)$, IL-10 $(\rho=0.48 ; P<0.001)$ and PAl-1 $(\rho=0.49 ; P<0.001)$.

Conclusion: The novel findings of our study are that septic patients with the T allele in the $372 \mathrm{~T} / \mathrm{C}$ genetic polymorphism of TIMP-1 showed higher serum TIMP-1 levels and lower survival rate. The determination of the 372 T/C genetic polymorphism of TIMP-1 thus has prognostic implications and could help in the selection of patients who may benefit from modulation of the MMP/TIMP balance.
\end{abstract}

Keywords: tissue inhibitor of matrix metalloproteinase-1, genetic, polymorphism, sepsis, mortality

\section{Introduction}

Sepsis represents a systemic response of the immune system to infection that leads to high mortality and costs $[1,2]$. The pathophysiologic mechanisms of sepsis are not

\footnotetext{
* Correspondence: lorentemartin@msn.com

'Intensive Care Unit, Hospital Universitario de Canarias, Ofra s/n La Laguna 38320, Santa Cruz de Tenerife, Spain

Full list of author information is available at the end of the article
}

well known and a better understanding of these processes may allow unmasking of other mortality risk factors.

Matrix metalloproteinases (MMPs) are a family of zinccontaining endoproteinases implicated in the degradation and remodelling of the extracellular matrix. The regulation of MMP activity is carried out by tissue inhibitors of matrix metalloproteinases (TIMPs). MMPs have a role in normal physiological functions such as the menstrual

\section{( Biomed Central}


cycle, morphogenesis, tissue remodelling and angiogenesis, and in diseases with abnormal extracellular matrix turnover, such as arthritis, tumour invasion, aneurysm formation and atherosclerosis [3]. The role of MMPs/ TIMPs in sepsis remains unclear; however, the results of some studies indicate that MMPs facilitate the recruitment of leukocytes from the bloodstream to the site of infection for eradication of the pathogen by proteolysis of the basement membrane [4], and modulate inflammatory $[4]$ and prothrombotic responses $[5,6]$.

Higher circulating levels of TIMP-1 have been reported in nonsurviving septic patients than in surviving septic patients [7-9]. An association between some genetic polymorphisms of the X-linked TIMP-1 gene and the risk of developing certain diseases has been reported [10-23], the $372 \mathrm{~T} / \mathrm{C}$ polymorphism being the variant most studied [10-16]. However, the relationship between genetic polymorphism of TIMP-1, circulating TIMP-1 levels and survival in patients with severe sepsis has not been examined.

The objective of this study was thus to determine whether there is an association between the $372 \mathrm{~T} / \mathrm{C}$ genetic polymorphism of TIMP-1, serum levels of TIMP1 and survival in patients with severe sepsis.

\section{Materials and methods}

\section{Design and subjects}

A multicentre, prospective, observational study was carried out in six Spanish ICUs. The study was approved by the Institutional Review Boards of the six hospitals: Hospital Universitario de Canarias (La Laguna, Santa Cruz de Tenerife, Spain), Hospital Universitario Nuestra Señora de Candelaria (Santa Cruz de Tenerife, Spain), Hospital Universitario Dr. Negrín (Las Palmas de Gran Canaria, Spain), Hospital Clínico Universitario de Valencia (Valencia, Spain), Hospital San Jorge (Huesca, Spain) and Hospital Insular (Las Palmas de Gran Canaria, Spain). Written informed consent was obtained from the patients or from the family members. All patients were Caucasian and suffered from severe sepsis. The diagnosis of severe sepsis was established according to the International Sepsis Definitions Conference [24].

Exclusion criteria were: age $<18$ years, pregnancy, lactation, HIV, white blood cell count $<10^{3} / \mathrm{mm}^{3}$, solid or haematological tumours, or immunosuppressive, steroid or radiation therapy.

\section{Variables recorded}

The following variables were recorded for each patient: sex, age, diabetes mellitus, site of infection, microorganism responsible, bloodstream infection, adequate empiric antimicrobial treatment, pressure of arterial oxygen/fraction of inspired oxygen, creatinine, bilirubin, leukocyte count, lactic acid, platelet count, International Normalised Ratio (INR), activated partial thromboplastin time
(aPTT) and Acute Physiology and Chronic Health Evaluation (APACHE) II score [25]. Measurements of circulating levels of TIMP-1, MMP-9, MMP-10, TNF $\alpha$, IL-10 and plasminogen activator inhibitor-1 (PAI-1), as well as the genetic determination of the TIMP-1 372 T/C polymorphism were carried out in peripheral blood. Survival at 30 days from ICU admission was the endpoint assessed.

\section{Determination of the $372 \mathrm{~T} / \mathrm{C}$ genetic polymorphism of TIMP-1 (rs4898)}

Genotyping was performed by PCR and restriction fragment length polymorphism analysis. DNA was prepared from $3 \mathrm{ml}$ peripheral blood using proteinase $\mathrm{K}$ treatment, phenol-chloroform extraction and ethanol precipitation. About 100 ng DNA were used as the template in PCR using the primers 5'-GCACATCACTACCTGCAGTCT-3' and 5'-GAAACAAGCCCACGATTTAG-3', flanking the $372 \mathrm{~T} / \mathrm{C}$ polymorphism (rs4898) of the TIMP-1 gene, and the temperature profile $94^{\circ} \mathrm{C}-55^{\circ} \mathrm{C}-72^{\circ} \mathrm{C}$ for 30 seconds each for 30 cycles. ( $\underline{C}$ denotes a mutation introduced in the primer in order to generate a BssSI restriction site (CACGAG) in the $\mathrm{C}$ allele, while the $\mathrm{T}$ allele remains uncut.) The amplified DNA was restricted with endonuclease BssSI (New England Biolabs, Boston, MA, USA) for 2 hours at $37^{\circ} \mathrm{C}$. The resulting DNA fragments were separated by gel electrophoresis in $2.5 \%$ agarose gel and visualised under ultraviolet light. In the absence of a BssSI site, a fragment of 175 base pairs was detected ( $\mathrm{T}$ allele), whereas fragments of 153 and 22 base pairs corresponded to the $\mathrm{C}$ allele. Genotyping was performed in a blinded manner.

\section{Determination of serum TIMP-1, MMP-9, MMP-10, TNF $\alpha$, IL-10 and plasma PAI-1 levels}

Blood samples were collected at ICU admission. Serum separator tubes were used to determine TIMP-1 concentration in serum; venous blood samples were taken and centrifuged within 30 minutes at $1,000 \times g$ for 15 minutes, and the serum was removed and frozen at $-80^{\circ} \mathrm{C}$ until measurement.

TIMP-1, MMP-9 and MMP-10 assays were performed at the Atherosclerosis Research Laboratory of CIMA University of Navarra (Pamplona, Spain). A specific ELISA (Quantikine ${ }^{\circledR}$; R\&D Systems, Abingdon, UK) was used in accordance with the manufacturer's instructions with a serum dilution of $1: 100,1: 80$ and $1: 2$, respectively. The interassay coefficient of variation was $<8 \%(n=20)$ and the detection limits for the assays were $0.15 \mathrm{ng} / \mathrm{ml}, 0.31$ $\mathrm{ng} / \mathrm{ml}$ and $78.1 \mathrm{pg} / \mathrm{ml}$, respectively.

TNF $\alpha$, IL-10 and PAI-1 assays were performed at the Laboratory Department of the Hospital Universitario de Canarias (La Laguna, Santa Cruz de Tenerife, Spain). TNF $\alpha$ and IL-10 determinations were performed by solid-phase chemiluminescent immunometric assays 
(Immulite ${ }^{\circledR}$; Siemens Healthcare Diagnostics Products, Llanberis, UK). The interassay coefficients of variation were $<6.5 \%(n=20)$ and $<9.9 \%(n=40)$, respectively, and detection limits for the assays were $1.7 \mathrm{pg} / \mathrm{ml}$ and $1 \mathrm{pg} / \mathrm{ml}$, respectively. PAI-1 antigen was assayed by specific ELISA (Imubind Plasma PAI-1 Elisa ${ }^{\mathrm{TM}}$; American Diagnostica, Inc., Stanford, CT, USA). This assay detects latent (inactive) and active forms of PAI- 1 and PAI- 1 complexes. The interassay coefficient of variation was $<5 \%(n=20)$ and the detection limit for the assay was $1 \mathrm{ng} / \mathrm{ml}$.

\section{Statistical methods}

This series of patients was a nonprobabilistic sample and the recruitment period was 18 months. This study included 192 patients from a previous publication [8]. Continuous variables are reported as medians and interquartile ranges. Categorical variables are reported as frequencies and percentages. Comparisons of continuous variables between groups were carried out using the Wilcoxon-Mann-Whitney test. Comparisons between groups on categorical variables were carried out with the chisquare test. The association between continuous variables was carried out using Spearman's rank correlation coefficient or Spearman's rho coefficient.

Thirty-day survival curves, using the $\mathrm{T}$ allele or non- $\mathrm{T}$ allele of the $372 \mathrm{~T} / \mathrm{C}$ genetic polymorphism of TIMP-1, were represented using the Kaplan-Meier method and compared by log-rank test. Multivariate logistic regression analysis was applied to data from the whole sample and separately by sex in order to determine the independent contribution of the $372 \mathrm{~T} / \mathrm{C}$ genetic polymorphism of TIMP-1, lactic acid levels, APACHE II score and sex to the prediction of mortality during the 30 -day period. We analysed, both globally and separately by sex, the relationship between TIMP-1 levels and 30-day survival, controlling for lactic acid level and APACHE score.

Odds ratios (ORs) and 95\% confidence intervals (CIs) were calculated as measures of the clinical impact of the predictor variables. Using linear regression modelling, we analysed the relationship between the $372 \mathrm{~T} / \mathrm{C}$ genetic polymorphism of TIMP-1 and the infection site as independent variables and TIMP-1 levels as the dependent variable. $P<0.05$ was considered statistically significant. Statistical analyses were performed with SPSS 17.0 (SPSS Inc., Chicago, IL, USA) and NCSS 2000 (Jerry Hintze, Kaysville, UT, USA).

\section{Results}

As shown in Table 1, a total of 275 patients with severe sepsis were included, 80 with genotype CC (or male hemizygous C), 55 with genotype CT and 140 with genotype TT (or male hemizygous T) of the $372 \mathrm{~T} / \mathrm{C}$ genetic polymorphism of TIMP-1 (rs4898). The calculated frequencies for the $C(0.393)$ and $T(0.607)$ alleles in our sample were similar to those obtained in the Exome Sequencing Project cohort population (0.467 and 0.533 , respectively) [26]. Since TIMP- 1 is located on the $\times$ chromosome, men and women were considered separately to test for HardyWeinberg equilibrium among our genotypes. Using chisquare tests to compare expected and observed genotypes, we found no significant deviation from Hardy-Weinberg predictions. There were no significant differences between different genotypes in age, diabetes mellitus, site of infection, microorganism responsible, bloodstream infection, adequate empiric antimicrobial treatment, pressure of arterial oxygen/fraction of inspired oxygen, bilirubin, leukocyte count, INR, aPTT and APACHE II score. However, patients with the $\mathrm{T}$ allele showed higher serum creatinine and lactic acid levels, and lower platelet count and male sex. Besides, patients with the $\mathrm{T}$ allele of the $372 \mathrm{~T} / \mathrm{C}$ genetic polymorphism of TIMP-1 showed higher serum levels of TIMP-1 $(P=0.004)$ and lower survival rate $(P=$ $0.02)$ than patients without the $\mathrm{T}$ allele.

Thirty-day survival according to the different $372 \mathrm{~T} / \mathrm{C}$ genetic polymorphism of TIMP-1 was analysed separately by sex. In men, we found higher survival in patients with the $\mathrm{C}$ allele than in those with the $\mathrm{T}$ allele (53/70 (75.7\%) vs. $67 / 111(60.4 \%) ; P=0.04)$. In women, we did not find significant differences in survival between patients with $\mathrm{C} / \mathrm{C}, \mathrm{C} / \mathrm{T}$ and $\mathrm{T} / \mathrm{T}$ expression (8/10 (80\%), 34/55 (61.8\%) vs. $17 / 29(58.6 \%) ; P=0.47)$.

As shown in Table 2, we found higher TIMP-1 levels in nonsurvivors than in survivors globally; separately by sex and $372 \mathrm{~T} / \mathrm{C}$ genetic polymorphism of TIMP-1, we found higher TIMP-1 levels in women and men with the $\mathrm{T}$ allele (Table 2).

We found an association between TIMP-1 levels and MMP-9 $(\rho=-0.19 ; P=0.002)$, MMP-10 $(\rho=0.55$; $P<0.001)$, TNF $\alpha(\rho=0.56 ; P<0.001)$, IL-10 $(\rho=0.48$; $P<0.001)$ and PAI-1 $(\rho=0.49 ; P<0.001)$ levels, INR $(\rho=$ -0.42; $P<0.001)$, aPTT $(\rho=0.29 ; P<0.001)$ and platelet count $(\rho=-0.18 ; P=0.002)$.

As shown in Table 3, multiple logistic regression analysis showed that the $\mathrm{T}$ allele of the $372 \mathrm{~T} / \mathrm{C}$ genetic polymorphism of TIMP-1 was associated with higher mortality at 30 days $(\mathrm{OR}=2.08 ; 95 \% \mathrm{CI}=1.06$ to $4.09 ; P=0.03)$. Separately by sex, we found a relationship between the $\mathrm{T}$ allele of the $372 \mathrm{~T} / \mathrm{C}$ genetic polymorphism of TIMP-1 and survival in men, after controlling for lactic acid level and APACHE II score $(\mathrm{OR}=1.44 ; 95 \% \mathrm{CI}=1.002$ to 2.072; $P=0.049)$, but not in women $(\mathrm{OR}=1.45 ; 95 \% \mathrm{CI}=$ 0.57 to $3.64 ; P=0.43$ ).

As shown in Table 3, multiple logistic regression analysis showed that TIMP-1 levels were associated with higher mortality at 30 days after controlling for lactic acid level and APACHE II score $(\mathrm{OR}=1.001 ; 95 \% \mathrm{CI}=1.0002$ to 
Table 1 Patient characteristics according to the $372 \mathrm{C} / \mathrm{T}$ genetic polymorphism of tissue inhibitor of matrix metalloproteinase-1

\begin{tabular}{|c|c|c|c|}
\hline Characteristic & Without T allele $(n=80)$ & With T allele $(n=195)$ & $P$ value \\
\hline Gender (male) & $70(87.5)$ & $111(56.9)$ & $<0.001$ \\
\hline Age (years) & $62(53$ to 72$)$ & 60 (48 to 69) & 0.12 \\
\hline Diabetes mellitus & $26(32.5)$ & $60(30.8)$ & 0.77 \\
\hline Myocardial infarction & $7(8.8)$ & $11(5.6)$ & 0.42 \\
\hline Chronic obstructive pulmonary disease & $12(15.0)$ & $26(13.3)$ & 0.70 \\
\hline Asthma & $2(2.5)$ & $4(2.1)$ & 0.99 \\
\hline Site of infection & & & 0.86 \\
\hline Respiratory & $47(58.8)$ & $106(54.4)$ & \\
\hline Abdominal & $23(28.8)$ & $57(29.2)$ & \\
\hline Neurological & $1(1.3)$ & $4(2.1)$ & \\
\hline Urinary & $2(2.5)$ & $12(6.2)$ & \\
\hline Skin & $3(3.8)$ & $8(4.1)$ & \\
\hline Endocarditis & $4(5.0)$ & $7(3.6)$ & \\
\hline Others & $0(0)$ & $1(0.5)$ & \\
\hline Bloodstream infection & $11(13.8)$ & $31(15.9)$ & 0.71 \\
\hline $\mathrm{PaO}_{2} / \mathrm{FIO}_{2}$ ratio & 150 (103 to 248) & 176 (107 to 262$)$ & 0.82 \\
\hline Creatinine (mg/dl) & 1.00 (0.85 to 2.03$)$ & $1.40(0.80$ to 2.40$)$ & 0.02 \\
\hline Bilirubin (mg/dl) & $0.80(0.43$ to 1.45$)$ & $0.90(0.46$ to 1.80$)$ & 0.64 \\
\hline Leukocytes $\left(\times 10^{3} / \mathrm{mm}^{3}\right)$ & 14.6 (10.2 to 20.0$)$ & 15.0 (9.1 to 20.4$)$ & 0.99 \\
\hline Lactic acid (mmol/l) & $1.80(1.20$ to 3.10$)$ & $2.30(1.30$ to 4.60$)$ & 0.02 \\
\hline Platelets $\left(\times 10^{3} / \mathrm{mm}^{3}\right)$ & 227 (132 to 303) & 165 (93 to 234$)$ & 0.007 \\
\hline INR & 1.32 (1.06 to 1.55$)$ & 1.35 (1.14 to 1.58$)$ & 0.46 \\
\hline aPTT (seconds) & 33 (29 to 44$)$ & $32(28$ to 41$)$ & 0.28 \\
\hline APACHE \| score & 19 (15 to 24$)$ & 20 (16 to 24$)$ & 0.41 \\
\hline TIMP-1 (ng/ml) & 523 (355 to 707) & 639 (444 to 880$)$ & 0.004 \\
\hline MMP-9 (ng/ml) & 759 (389 to 1,224$)$ & 606 (275 to 1,022$)$ & 0.11 \\
\hline MMP-10 (pg/ml) & $1706(1,016$ to 2,539$)$ & $1,795(1,237$ to 3,514$)$ & 0.12 \\
\hline TNF $\alpha(p g / m l)$ & $27.8(18.1$ to 47.1$)$ & $31.8(20.1$ to 57.9$)$ & 0.37 \\
\hline IL-10 (pg/ml) & 10.1 (5.6 to 55.4 ) & $14.55(6.0$ to 60.5$)$ & 0.36 \\
\hline PAl-1 (ng/ml) & $39.9(25.2$ to 63.4$)$ & 44.8 (24.6 to 71.5$)$ & 0.48 \\
\hline Survivors at 30 days & $61(76.3)$ & $118(60.5)$ & 0.02 \\
\hline
\end{tabular}

Data presented as number (percentage) or median (25th to 75th percentile). APACHE, Acute Physiology and Chronic Health Evaluation; aPT, activated partial thromboplastin time; INR, International Normalised Ratio; MMP, matrix metalloproteinase; $\mathrm{PaO}_{2} / \mathrm{FIO}_{2}$, pressure of arterial oxygen/fraction inspired oxygen; PAI-1, plasminogen activator inhibitor-1; TIMP, tissue inhibitor of matrix metalloproteinase.

Table 2 TIMP-1 levels in surviving and nonsurviving patients according to sex and 372 T/C genetic polymorphism

\begin{tabular}{llll}
\hline & Survival & Nonsurvival & $P$ value \\
\hline All patients & $529(355$ to 706$)$ & $805(510$ to 1,027$)$ & $<0.001$ \\
Women & $436(345$ to 775$)$ & $662(500$ to 824$)$ & 0.43 \\
$\mathrm{C} / \mathrm{C}$ & $583(415$ to 819$)$ & $862(506$ to 1,055$)$ & 0.03 \\
$\mathrm{C} / \mathrm{T}$ & $465(284$ to 754$)$ & $742(413$ to 1,177$)$ & 0.046 \\
$\mathrm{~T} / \mathrm{T}$ & & & 0.11 \\
Men & $500(333$ to 657$)$ & $696(370$ to 936$)$ & $<0.001$ \\
C allele & $557(437$ to 715$)$ & $814(616$ to 1,055$)$ & \\
\hline T allele &
\end{tabular}

Data $(\mathrm{ng} / \mathrm{ml}$ ) presented as median (25th to 75th percentile). TIMP, tissue inhibitor of matrix metalloproteinase. \{AU Query: Confirm table caption, contents and footnote after editing to style\} 
Table 3 Multiple logistic regression analysis to predict 30-day mortality.

\begin{tabular}{|c|c|c|c|}
\hline & Odds ratio & $95 \%$ confidence interval & $P$ value \\
\hline \multicolumn{4}{|c|}{ First model including all patients } \\
\hline Lactic acid & 1.19 & 1.07 to 1.32 & 0.001 \\
\hline APACHE ॥ & 1.08 & 1.04 to 1.13 & $<0.001$ \\
\hline Gender female & 1.26 & 0.68 to 2.33 & 0.46 \\
\hline Presence of $\mathrm{T}$ allele ${ }^{\mathrm{a}}$ & 2.08 & 1.06 to 4.09 & 0.03 \\
\hline \multicolumn{4}{|c|}{ Second model including only women } \\
\hline Lactic acid & 1.18 & 1.02 to 1.36 & 0.03 \\
\hline APACHE ॥ & 1.10 & 1.02 to 1.18 & 0.009 \\
\hline Presence of $\mathrm{T}$ allele $\mathrm{e}^{\mathrm{a}}$ & 1.45 & 0.57 to 3.64 & 0.43 \\
\hline \multicolumn{4}{|c|}{ Third model including only men } \\
\hline Lactic acid & 1.21 & 1.04 to 1.40 & 0.01 \\
\hline APACHE ॥ & 1.08 & 1.02 to 1.13 & 0.008 \\
\hline Presence of $\mathrm{T}$ allele $\mathrm{e}^{\mathrm{a}}$ & 1.44 & 1.002 to 2.072 & 0.049 \\
\hline \multicolumn{4}{|c|}{ Four model including all patients } \\
\hline Lactic acid & 1.13 & 1.02 to 1.27 & 0.03 \\
\hline APACHE ॥ & 1.08 & 1.03 to 1.13 & $<0.001$ \\
\hline TIMP-1 levels & 1.001 & 1.0002 to 1.002 & 0.008 \\
\hline \multicolumn{4}{|c|}{ Five model including only women } \\
\hline Lactic acid & 1.13 & 0.95 to 1.34 & 0.16 \\
\hline APACHE ॥ & 1.14 & 1.04 to 1.24 & 0.003 \\
\hline TIMP-1 levels & 1.001 & 1.0002 to 1.003 & 0.048 \\
\hline \multicolumn{4}{|c|}{ Six model including only men } \\
\hline Lactic acid & 1.13 & 1.06 to 1.62 & 0.01 \\
\hline APACHE ॥ & 1.10 & 1.02 to 1.19 & 0.02 \\
\hline TIMP-1 levels & 1.0001 & 0.999 to 1.001 & 0.48 \\
\hline
\end{tabular}

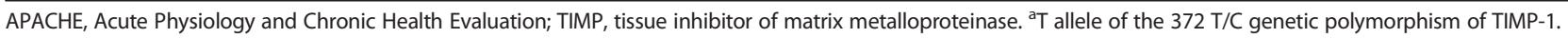

1.002; $P=0.008)$. Separately by sex, we found a relationship between TIMP-1 levels and survival in women, after controlling for lactic acid level and APACHE II score (OR $=1.001 ; 95 \% \mathrm{CI}=1.0002$ to $1.003 ; P=0.048)$, but not in men $(\mathrm{OR}=1.0001 ; 95 \% \mathrm{CI}=0.999$ to $1.001 ; P=0.48)$.

Linear regression analysis showed that TIMP-1 levels were associated with the $372 \mathrm{~T} / \mathrm{C}$ genetic polymorphism of TIMP-1 (regression coefficient $=114.4 ; 95 \% \mathrm{CI}=$ 31.71 to $197.14 ; P=0.007)$, but not with site of infection (regression coefficient $=105.7 ; 95 \% \mathrm{CI}=-45.12$ to 256.48; $P=0.17$ ).

Survival analysis showed that patients with the $\mathrm{T}$ allele of the 372 T/C genetic polymorphism of TIMP-1 presented lower 30-day survival than those without the $\mathrm{T}$ allele $\left(\chi^{2}=5.77 ; P=0.016\right)$ (Figure 1$)$.

\section{Discussion}

The novel findings of our study were that there is an association between the $372 \mathrm{~T} / \mathrm{C}$ genetic polymorphism of TIMP-1 (rs4898), circulating levels of TIMP-1 and 30 -day survival in patients with severe sepsis. Patients with the $\mathrm{T}$ allele in the $372 \mathrm{~T} / \mathrm{C}$ genetic polymorphism of TIMP-1 showed higher serum TIMP-1 levels and lower survival rate.
Although the exact mechanism by which this synonymous SNP might affect function is unknown, the 372 T/C genetic polymorphism of TIMP-1 has been associated with increased risk of developing certain diseases [10-16]. However, an association between the $372 \mathrm{~T} / \mathrm{C}$ genetic polymorphism of TIMP-1 and survival in patients with severe sepsis has not been previously reported. The results of the different studies are controversial; some found that the $\mathrm{C}$ allele was associated with higher risk of certain diseases [10-13] while others showed that the $\mathrm{T}$ allele was associated with higher risk [14-16]. In the present study, septic patients with the T allele had a lower rate of survival at 30 days.

A previous study showed that humans carrying the $\mathrm{T}$ allele in the $372 \mathrm{~T} / \mathrm{C}$ genetic polymorphism of TIMP-1 had increased susceptibility to Crohn's disease and presented lower levels of TIMP-1 in surgically resected macroscopically inflamed tissue [15]. In our study, however, we found that septic patients with this $\mathrm{T}$ allele had a lower survival rate and showed higher serum levels of TIMP-1. This is consistent with reports of higher circulating levels of TIMP-1 in nonsurviving septic patients than in surviving septic patients [7-9]. 


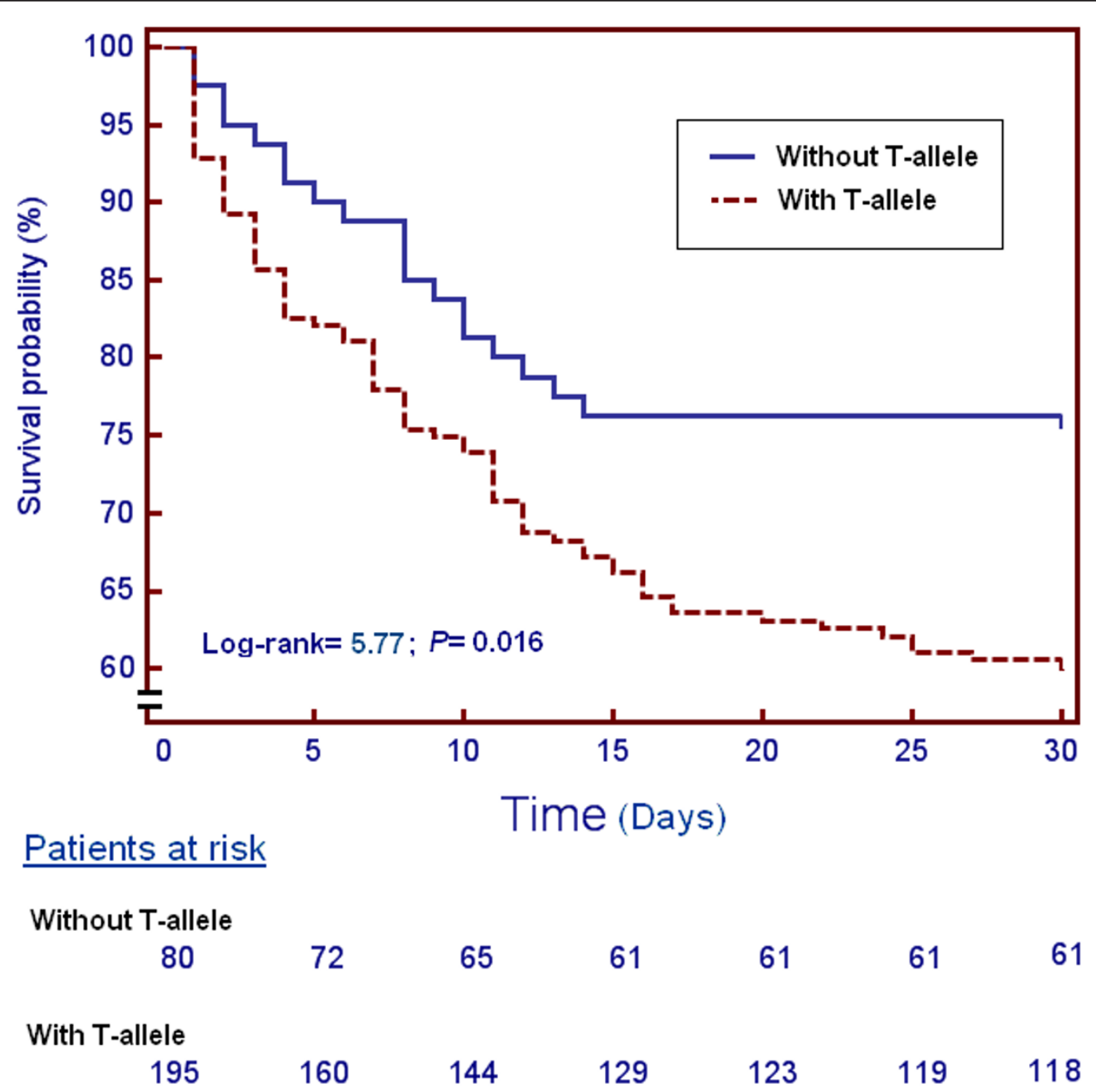

Figure 1 Thirty-day survival according the T allele in the $372 \mathrm{C} / \mathrm{T}$ genetic polymorphism of TIMP-1. Kaplan-Meier curves showing the cumulative proportion of survival patients at 30 days according to the presence or not of the T allele in the $372 \mathrm{C} / \mathrm{T}$ genetic polymorphism of tissue inhibitor of matrix metalloproteinase (TIMP)-1.

There is a relationship between coagulation and inflammation response in sepsis [27-29] and it is possible that MMPs/TIMPs play a role in that response. In our series, septic patients carrying the $\mathrm{T}$ allele showed significantly higher serum TIMP-1 levels and lower survival rate. The reason for this is not clear; TIMP-1 forms noncovalent bimolecular complexes with the active and latent forms of MMP-9, and reduces MMP-9 activity [3,4]. Some studies have reported that MMP-9 inhibits platelet aggregation $[30,31]$, that there is a positive correlation between TIMP1 and PAI-1 [32,33] and that there is a positive correlation between TIMP-1 and plasma homocysteine [32]. We found, for the first time in septic patients, a positive association between TIMP-1 levels and PAI-1 levels and aPTT, and a negative association between TIMP-1 levels and the INR and platelet count - these data suggest that these patients had a higher anti-fibrinolytic state and activation of coagulation. We found that septic patients carrying the $\mathrm{T}$ allele in the $372 \mathrm{~T} / \mathrm{C}$ genetic polymorphism of TIMP-1 had higher TIMP-1 levels than those without it. We therefore believe that septic patients carrying the $\mathrm{T}$ allele in the $372 \mathrm{~T} / \mathrm{C}$ genetic polymorphism of TIMP-1 could have a prothrombotic/antifibrinolytic profile, responsible for capillary thrombosis, multiple organ dysfunction and, finally, early death.

The $372 \mathrm{~T} / \mathrm{C}$ genetic polymorphism of TIMP-1 is located on the $\times$ chromosome, which means that men have the $\mathrm{C}$ or $\mathrm{T}$ allele, and women have $\mathrm{C} / \mathrm{C}, \mathrm{C} / \mathrm{T}$ or $\mathrm{T} / \mathrm{T}$. This aspect is important since there are differences in the findings according to patient gender. On the one hand, globally, we found that patients without the $\mathrm{T}$ allele showed better 30-day survival than those with the $\mathrm{T}$ allele. 
Separately by sex, men without the $\mathrm{T}$ allele had better 30 day survival than those with the $\mathrm{T}$ allele but no differences in survival were found between women patients with $\mathrm{C} / \mathrm{C}$, $\mathrm{C} / \mathrm{T}$ and $\mathrm{T} / \mathrm{T}$ alleles. On the other hand, globally, we found that nonsurvivors showed higher TIMP-1 levels than survivors. Stratified by sex, nonsurviving women with $\mathrm{C} / \mathrm{T}$ and $\mathrm{T} / \mathrm{T}$ and nonsurviving men with the $\mathrm{T}$ allele had higher TIMP-1 levels than survivors; however, we did not find differences in TIMP-1 levels between survivors and nonsurvivors in women with $\mathrm{C} / \mathrm{C}$ or men with the $\mathrm{C}$ allele. Taken together, our results indicate an association between the T allele and TIMP-1 levels, and that higher TIPM-1 levels increased early mortality.

A noteworthy finding of the present study was that TIMP-1 levels in both surviving and nonsurviving patients were lower than those described in other series $[7,9]$; however, the levels were significantly higher in nonsurvivors than in survivors in all studies.

From a therapeutic perspective, modulators of MMP/ TIMP activity have been used successfully in septic animal models, reducing TIMP- 1 and improving the prognosis [34,35]. Determination of the $372 \mathrm{~T} / \mathrm{C}$ genetic polymorphism of TIMP-1 could thus help in the selection of patients who may benefit from modulation of MMP/TIMP activity.

The present study has certain limitations. First, the sample size was relatively small; nevertheless, our nonprobabilistic sample was large enough to be able to show an association between the $372 \mathrm{~T} / \mathrm{C}$ genetic polymorphism of TIMP-1 and 30-day survival. Second, it could be interesting to determine other SNPs of TIMP-1; however, we tested rs4898 because this SNP has previously been associated with other diseases [10-16]. rs4898 is a synonymous coding SNP, but it is in strong linkage disequilibrium with other TIMP-1 polymorphisms, as documented in the HapMap database for European Community populations [26]. The rs4898 SNP can thus be used as a tag SNP for the region of interest. It is possible that this rs4898 SNP is linked to other SNPs associated with the same effect, as was previously proposed in a study by Skarmoutsou and colleagues to explain the association between this polymorphism and systemic sclerosis [16]. Third, we did not determine the rs4898 SNP in healthy control subjects; however, the objective of our study was not to determine the association between the occurrence of sepsis and the polymorphism, but rather the association between sepsis survival and the polymorphism.

\section{Conclusion}

The novel findings of our study are that septic patients with the $\mathrm{T}$ allele in the $372 \mathrm{~T} / \mathrm{C}$ genetic polymorphism of TIMP-1 showed higher serum TIMP-1 levels and lower survival rate. Determination of the $372 \mathrm{~T} / \mathrm{C}$ genetic polymorphism of TIMP-1 thus has prognostic implications and could help in the selection of patients who may benefit from modulation of the MMP/TIMP balance.

\section{Key messages}

- Septic patients with $\mathrm{T}$ allele in the $372 \mathrm{~T} / \mathrm{C}$ genetic polymorphism of TIMP-1 showed higher serum TIMP-1 levels and lower survival rate

- The determination of the $372 \mathrm{~T} / \mathrm{C}$ genetic polymorphism of TIMP-1 has prognostic implications and could help in the selection of patients who may benefit from modulation of the MMP/TIMP balance.

\section{Abbreviations}

APACHE: Acute Physiology and Chronic Health Evaluation; aPTT: activated partial thromboplastin time; INR: International Normalised Ratio; Cl: confidence interval; ELISA: enzyme-linked immunosorbent assay; MMP: matrix metalloproteinase; OR: odds ratio; PAI-1: plasminogen activator inhibitor-1; PCR: polymerase chain reaction; SNP: single nucleotide polymorphism; TIMP: tissue inhibitor of matrix metalloproteinase; TNF: tumour necrosis factor

\section{Authors' contributions}

LLo conceived, designed and coordinated the study, participated in acquisition of data, and drafted the manuscript. MM, JS-V, JB, LLa and CD participated in acquisition of data. AJ interpreted the data. FP and ES carried out the molecular genetic studies. JMB-L, JAP, JO and JAR carried out the immunoassays. All authors read and approved the final manuscript.

\section{Competing interests}

The authors declare that they have no competing interests.

\section{Acknowledgements}

This study was supported, in part, by the grants FIS/PI-10-1572, I3SNS-INT-11063 and I3SNS-INT-12-087 from Instituto de Salud Carlos III (Madrid, Spain) and by UTE Project CIMA (University of Navarra).

\section{Author details}

${ }^{1}$ Intensive Care Unit, Hospital Universitario de Canarias, Ofra s/n La Laguna 38320, Santa Cruz de Tenerife, Spain. ${ }^{2}$ Intensive Care Unit, Hospital Universitario Nuestra Señora Candelaria, Carretera Rosario s/n, Santa Cruz Tenerife 38010, Spain. ${ }^{3}$ Research Unit, Hospital Universitario de Canarias, La Laguna 38320, Santa Cruz de Tenerife, Spain. ${ }^{4}$ Intensive Care Unit, Hospital Universitario Dr. Negrín, Barranco de la Ballena s/n, Las Palmas de Gran Canaria 35010, Spain. Intensive Care Unit, Hospital Clínico Universitario de Valencia, Avenida Blasco Ibáñez n’17, Valencia 46004, Spain. ${ }^{6}$ Intensive Care Unit, Hospital San Jorge de Huesca, Avenida Martínez de Velasco n³6,

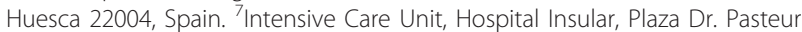
s/n, Las Palmas de Gran Canaria 35016, Spain. ${ }^{8}$ Laboratory Deparment, Hospital Universitario de Canarias, Ofra s/n, La Laguna 38320, Santa Cruz de Tenerife, Spain. ${ }^{9}$ Atherosclerosis Research Laboratory, CIMA-University of Navarra, Avenida Pío XII no55, Pamplona 31008, Spain.

Received: 30 January 2013 Revised: 4 April 2013

Accepted: 25 May 2013 Published: 25 May 2013

\section{References}

1. Vincent JL, Sakr Y, Sprung CL, Ranieri VM, Reinhart K, Gerlach H, Moreno R, Carlet J, Le Gall JR, Payen D, Sepsis Occurrence in Acutely III Patients Investigators: Sepsis in European intensive care units: results of the SOAP study. Crit Care Med 2006, 34:344-353.

2. Angus DC, Linde-Zwirble WT, Lidicker J, Clermont G, Carcillo J, Pinsky MR: Epidemiology of severe sepsis in the United States: analysis of incidence, outcome, and associated costs of care. Crit Care Med 2001, 29:1303-1310.

3. Brinckerhoff $C E$, Matrisian LM: Matrix metalloproteinases: a tail of a frog that became a prince. Nat Rev Mol Cell Biol 2002, 3:207-214. 
4. Elkington PT, O'Kane CM, Friedland JS: The paradox of matrix metalloproteinases in infectious disease. Clin Exp Immunol 2005 142:12-20.

5. Lijnen $\mathrm{H}$ : Matrix metalloproteinases and cellular fibrinolytic activity. Biochemistry (MosC) 2002, 67:92-98.

6. Santos-Martínez MJ, Medina C, Jurasz P, Radomski MW: Role of metalloproteinases in platelet function. Thromb Res 2008, 121:535-542.

7. Hoffmann U, Bertsch T, Dvortsak E, Liebetrau C, Lang S, Liebe V, Huhle G, Borggrefe $M$, Brueckmann M: Matrix-metalloproteinases and their inhibitors are elevated in severe sepsis: prognostic value of TIMP-1 in severe sepsis. Scand J Infect 2006, 38:867-872.

8. Lorente L, Martín MM, Labarta L, Díaz C, Solé-Violán J, Blanquer J, Orbe J, Rodríguez JA, Jiménez A, Borreguero-León JM, Belmonte F, Medina JC, Llimiñana MC, Ferrer-Agüero JM, Ferreres J, Mora ML, Lubillo S, Sánchez M, Barrios Y, Sierra A, Páramo JA: Matrix metalloproteinase-9, -10, and tissue inhibitor of matrix metalloproteinases-1 blood levels as biomarkers of severity and mortality in sepsis. Crit Care 2009, 13:R158.

9. Lauhio A, Hästbacka J, Pettilä V, Tervahartiala T, Karlsson S, Varpula T, Varpula M, Ruokonen E, Sorsa T, Kolho E: Serum MMP-8, -9 and TIMP-1 in sepsis: high serum levels of MMP-8 and TIMP-1 are associated with fatal outcome in a multicentre, prospective cohort study. Hypothetical impact of tetracyclines. Pharmacol Res 2011, 64:590-594.

10. Hung KH, Hung HW, Yang HB, Lu CC, Wu JJ, Sheu BS: Host single nucleotide polymorphisms of MMP-9 -1562/TIMP-1 372 have gender differences in the risk of gastric intestinal metaplasia after Helicobacter pylori infection. Helicobacter 2009, 14:580-587.

11. Yi YC, Chen MK, Chen LY, Ho ES, Ying TH, Wang PH, Yang SF: Genetic polymorphism of the tissue inhibitor of metalloproteinase-1 is associated with an increased risk of endometrial cancer. Clin Chim Acto 2009, 409:127-131.

12. Wei JC, Lee HS, Chen WC, Shiu LJ, Yang SF, Wong RH: Genetic polymorphisms of the matrix metalloproteinase-3 (MMP-3) and tissue inhibitors of matrix metalloproteinases-1 (TIMP-1) modulate the development of ankylosing spondylitis. Ann Rheum Dis 2009, 68:1781-1786.

13. Meijer MJ, Mieremet-Ooms MA, Sier CF, van Hogezand RA, Lamers CB, Hommes DW, Verspaget HW: Matrix metalloproteinases and their tissue inhibitors as prognostic indicators for diagnostic and surgical recurrence in Crohn's disease. Inflamm Bowel Dis 2009, 15:84-92.

14. Indelicato M, Chiarenza V, Libra M, Malaponte G, Bevelacqua V, Marchini M, McCubrey JA, Stivala F, Scorza R, Mazzarino MC: Analysis of TIMP-1 gene polymorphisms in Italian sclerodermic patients. J Clin Lab Anal 2006, 20:173-176.

15. Meijer MJ, Mieremet-Ooms MA, van Hogezand RA, Lamers CB, Hommes DW, Verspaget HW: Role of matrix metalloproteinase, tissue inhibitor of metalloproteinase and tumor necrosis factor-alpha single nucleotide gene polymorphisms in inflammatory bowel disease. World J Gastroenterol 2007, 13:2960-2966.

16. Skarmoutsou E, D'Amico F, Marchini M, Malaponte G, Scorza R, Mazzarino MC: Association of TIMP-1 +372 SNP with digital ulcer manifestation in female systemic sclerosis patients. Hum Immunol 2012, 73:950-953.

17. van Diemen CC, Postma DS, Siedlinski M, Blokstra A, Smit HA, Boezen HM: Genetic variation in TIMP1 but not MMPs predict excess FEV1 decline in two general population-based cohorts. Respir Res 2011, 12:57.

18. Ogata T, Shibamura H, Tromp G, Sinha M, Goddard KA, Sakalihasan N, Limet R, MacKean GL, Arthur C, Sueda T, Land S, Kuivaniemi H: Genetic analysis of polymorphisms in biologically relevant candidate genes in patients with abdominal aortic aneurysms. J Vasc Surg 2005, 41:1036-1042.

19. Lose F, Thompson PJ, Duffy D, Stewart GA, Kedda MA: A novel tissue inhibitor of metalloproteinase-1 (TIMP-1) polymorphism associated with asthma in australian women. Thorax 2005, 60:623-628.

20. Kumar M, Bhadoria DP, Dutta K, Singh S, Gupta J, Kumar R, Chhillar AK, Yadav V, Singh B, Sharma GL: Combinatorial effect of TIMP-1 and a1AT gene polymorphisms on development of chronic obstructive pulmonary disease. Clin Biochem 2011, 44:1067-1073.

21. Xiao B, Tian W, Zhao DH, Wu CA, Wang N, Zhang YZ: Relationship between $666 \mathrm{C}>\mathrm{T}$ polymorphism of TIMP-1 and lumbar intervertebral disc degeneration. Zhonghua Yi Xue Za Zhi 2010, 90:2939-2942.
22. Burkhardt J, Petit-Teixeira E, Teixeira VH, Kirsten H, Garnier S, Ruehle S, Oeser C, Wolfram G, Scholz M, Migliorini P, Balsa A, Westhovens R, Barrera P, Alves H, Pascual-Salcedo D, Bombardieri S, Dequeker J, Radstake TR, Van Riel P, van de Putte L, Bardin T, Prum B, BucheggerPodbielski U, Emmrich F, Melchers I, Cornelis F, Ahnert P: Association of the X-chromosomal genes TIMP1 and IL9R with rheumatoid arthritis. J Rheumatol 2009, 36:2149-2157.

23. Valdes AM, Hassett G, Hart DJ, Spector TD: Radiographic progression of lumbar spine disc degeneration is influenced by variation at inflammatory genes: a candidate SNP association study in the Chingford cohort. Spine (Phila Pa 1976) 2005, 30:2445-2451.

24. Levy MM, Fink MP, Marshall JC, Abraham E, Angus D, Cook D, Cohen J, Opal SM, Vincent JL, Ramsay G, International Sepsis Definitions Conference: 2001 SCCM/ ESICM/ ACCP/ATS/SIS International Sepsis Definitions Conference. Intensive Care Med 2003, 29:530-538.

25. Knaus WA, Draper EA, Wagner DP, Zimmerman JE: APACHE II: a severity of disease classification system. Crit Care Med 1985, 13:818-829.

26. Single Nucleotide Polymorphism Database. [http://www.ncbi.nlm.nih.gov/ projects/SNP/snp_ref.cgi? rs $=4898]$.

27. Kinasewitz GT, Yan SB, Basson B, Comp P, Russell JA, Cariou A, Um SL, Utterback B, Laterre PF, Dhainaut JF, PROWESS Sepsis Study Group: Universal changes in biomarkers of coagulation and inflammation occur in patients with severe sepsis, regardless of causative micro-organism [ISRCTN74215569]. Crit Care 2004, 8:R82-R90.

28. Esmon CT: Interactions between the innate immune and blood coagulation systems. Trends Immunol 2004, 25:536-542.

29. Schultz MJ, Haitsma JJ, Zhang H, Slutsky AS: Pulmonary coagulopathy as a new target in therapeutic studies of acute lung injury or pneumonia -a review. Crit Care Med 2006, 34:871-877.

30. Sheu JR, Fong TH, Liu CM, Shen MY, Chen TL, Chang Y, Lu MS, Hsiao G: Expression of matrix metalloproteinase- 9 in human platelets: regulation of platelet activation in in vitro and in vivo studies. Br J Pharmacol 2004, 143:193-201.

31. Lee YM, Lee JJ, Shen MY, Hsiao G, Sheu JR: Inhibitory mechanisms of activated matrix metalloproteinase-9 on platelet activation. Eur $J$ Pharmacol 2006, 537:52-58

32. Aznaouridis K, Vlachopoulos C, Dima I, Vasiliadou C, loakeimidis N, Baou K, Stefanadi E, Stefanadis C: Divergent associations of tissue inhibitors of metalloproteinases- 1 and -2 with the prothrombotic/fibrinolytic state. Atherosclerosis 2007, 195:212-215.

33. Cavusoglu E, Ruwende C, Chopra V, Yanamadala S, Eng C, Clark LT, Pinsky DJ, Marmur JD: Tissue inhibitor of metalloproteinase-1 (TIMP-1) is an independent predictor of all-cause mortality, cardiac mortality, and myocardial infarction. Am Heart J 2006, 151:1101, e1-e8.

34. Zhu S, Ashok M, Li J, Li W, Yang H, Wang P, Tracey KJ, Sama AE, Wang H: Spermine protects mice against lethal sepsis partly by attenuating surrogate inflammatory markers. Mol Med 2009, 15:275-282.

35. Ho CH, Hsu SP, Yang CC, Lee YH, Chien CT: Sialic acid reduces acute endotoxemia-induced liver dysfunction in the rat. Shock 2009, 32:228-235.

doi:10.1186/cc12739

Cite this article as: Lorente et al:: The $372 \mathrm{~T} / \mathrm{C}$ genetic polymorphism of TIMP-1 is associated with serum levels of TIMP-1 and survival in patients with severe sepsis. Critical Care 2013 17:R94.

\section{Submit your next manuscript to BioMed Central and take full advantage of:}

- Convenient online submission

- Thorough peer review

- No space constraints or color figure charges

- Immediate publication on acceptance

- Inclusion in PubMed, CAS, Scopus and Google Scholar

- Research which is freely available for redistribution

Submit your manuscript at www.biomedcentral.com/submit
C Biomed Central 